\title{
Human intraoral myiasis
}

\author{
Miíase humana intrabucal \\ Miasis intraoral humana
}

Received: 09/02/2021 | Reviewed: 09/09/2021 | Accept: 09/10/2021 | Published: 09/13/2021

Deise Ponzoni

ORCID: https://orcid.org/0000-0003-2855-7495 Federal University of Rio Grande do Sul, Brazil E-mail: deise.ponzoni@ufrgs.br

Alexandre Silva de Quevedo ORCID: https://orcid.org/0000-0001-5613-8015 Federal University of Rio Grande do Sul, Brazil E-mail: quevedoalexandre@ hotmail.com

Renan Cavalheiro Langie ORCID: https://orcid.org/0000-0001-6249-2862 Federal University of Rio Grande do Sul, Brazil E-mail: renanlangie@gmail.com

Vinícius Matheus Szydloski ORCID: https://orcid.org/0000-0001-7559-7735 Federal University of Rio Grande do Sul, Brazil E-mail: viniszy@hotmail.com

Edela Puricelli

ORCID: https://orcid.org/0000-0003-1318-709X Federal University of Rio Grande do Sul, Brazil E-mail: epuricelli@uol.com.br

\begin{abstract}
Introduction: Myiasis, a pathological condition in which dipteran larvae infect and parasitise a host, usually occurs in tropical and subtropical climate countries. Larvae can infect different parts of the human body. Intraoral human myiasis is considered a rare condition that is associated with systemic, local and environmental predisposing factors. Objective and case report: This case report describes a systemically compromised patient with expressive intraoral infestation causing pain, bleeding and tissue necrosis. The patient was treated in a hospital environment under the effects of general anaesthesia. Treatment consisted of removal of the larvae, surgical debridement and use of ivermectin. Final considerations: The control of hygiene conditions by the family/caregivers and dental care are determinant for the prevention of intraoral human myiasis, especially in patients with defective self-care presenting with dentofacial skeletal alterations that make normal mouth closure impossible. The control of the disease is a determinant to avoid potential complications, such as airway involvement, secondary infections and sepsis.
\end{abstract}

Keywords: Myiasis; Mouth; Surgery, Oral.

\section{Resumo}

Introdução: A miíase é definida como uma condição patológica, onde larvas dípteras causam a infestação e parasitam um hospedeiro. Geralmente ocorre em países de clima tropical e subtropical. As larvas podem infestar diferentes partes do corpo humano. A miíase humana intrabucal é considerada uma condição rara, com baixa incidência e que está associada a fatores predisponentes sistêmicos, locais e ambientais. Objetivo e relato do caso: $\mathrm{O}$ artigo tem por objetivo apresentar o relato de caso de um paciente comprometido sistemicamente, com infestação intrabucal expressiva, causando dor, sangramento e necrose tecidual. O paciente foi atendido em ambiente hospitalar, sob efeitos de anestesia geral. O tratamento consistiu na remoção das larvas, desbridamento cirúrgico e uso de ivermectina. Considerações finais: $O$ controle das condições de higiene por familiares/cuidadores e a assistência odontológica são determinantes para prevenção da miíase humana intrabucal, especialmente em pacientes sem condições de autocuidado e que apresentem alterações esqueléticas dentofaciais, impossibilitando o selamento labial. A contenção da doença é determinante, também para evitar complicações potenciais, como o risco de envolvimento da via aérea, infecções secundárias e sepse.

Palavras-chave: Miíase; Boca; Cirurgia Bucal.

\section{Resumen}

Introducción: La miasis se define como una condición patológica en la que las larvas de dípteros causan infestación y parasitan a un hospedador. Suele ocurrir en países con clima tropical y subtropical. Las larvas pueden infestar diferentes partes del cuerpo humano. La miasis intraoral humana se considera una enfermedad rara, de baja incidencia y asociada a factores predisponentes sistémicos, locales y ambientales. Objetivo y reporte de caso: El artículo tiene 
como objetivo presentar el reporte de caso de un paciente sistémicamente comprometido, con importante infestación intraoral, causando dolor, sangrado y necrosis tisular. El paciente fue tratado en un ambiente hospitalario, bajo los efectos de anestesia general. El tratamiento consistió en la extracción de larvas, desbridamiento quirúrgico y uso de ivermectina. Consideraciones finales: El control de las condiciones de higiene por parte de los familiares / cuidadores y el cuidado dental son cruciales para la prevención de la miasis intraoral humana, especialmente en pacientes sin condiciones de autocuidado y que presentan alteraciones esqueléticas dentofaciales, imposibilitando el sellado de labios. Contener la enfermedad también es fundamental para evitar posibles complicaciones, como el riesgo de afectación de las vías respiratorias, infecciones secundarias y sepsis.

Palabras clave: Miasis; Boca; Cirugía Bucal.

\section{Introduction}

Myiasis is an ectoparasitic infestation of viable or necrotic tissues of living vertebrates (animals and humans) by larvae of several species of the order Diptera (Ahmadpour et al., 2019; Batista et al., 2019; Bernhardt, Finkelmeier, Verhoff, \& Amendt, 2019; Calvopina et al., 2020; de Arruda et al., 2017; Duque \& Ardila, 2011; Girardi \& Scrofernecker, 2017; Faridnia et al., 2019). The order Diptera, present mainly in tropical and subtropical regions, is one of the largest orders of insects and its representatives are abundant in both individuals and species, in addition to most species presenting a cosmopolitan distribution (Britto et al., 2008; de Arruda et al., 2017). Several species of dipterans have been associated with human myiasis. However, in Brazil, Cochliomyia hominivorax is the most important species causing primary myiasis in man, herds and pets (Costa-Júnior et al., 2019).

Zoonotic infestations by dipteran larvae are of great importance in human health. The term myiasis was introduced by Hope in 1840. Human myiasis has a worldwide distribution and is endemic (Calvopina et al., 2020; Faridnia et al., 2019). It is considered rare in most regions of the world, due to the fact that dipteran species associated with this condition do not survive in areas of unfavourable climatic conditions. However, the vast mobility of human populations, including trips to endemic areas, has resulted in an increased frequency of cases of myiasis in travelers returning from these areas. One of the first reports of human myiasis in Brazil was documented by Brandão and Menezes (1875) and included 30 cases, mainly involving the nasal cavities (Costa-Júnior et al., 2019; Kuria \& Oyedeji, 2020).

More than half of the human cases present with involvement of the head and neck region, and the oral cavity is another site of occurrence. The incidence of intraoral myiasis is less frequent than extraoral, since oral tissues in most individuals are not permanently exposed (de Arruda et al., 2017). The first description of oral myiasis was made by Laurence in 1909. The most commonly involved site in the oral cavity is the palate, and there may be situations in which more than one site is affected. The correlation between anatomical location, presence of lesions, presence of systemic problems and sanitary risks are determinants of the onset of the condition (de Arruda et al., 2017; Laurence, 1909).

Treatment of myiasis, regardless of the affected site, is based on the mechanical removal of larvae, surgical debridement of devitalised tissues and drug administration (Ashour, 2019; Batista et al., 2019; de Arruda et al., 2017; Ribeiro, de Almeida, Lopes, Castro, \& Pinheiro, 2012).

\section{Methodology}

This was a retrospective, descriptive and observational clinical case report (Alsaywid \& Abdulhaq, 2019; Estrela, 2018) of a patient presenting with myiasis of the oral cavity who was treated under general anaesthesia in a hospital environment. Descriptive data were collected through access to physical and electronic medical records, after authorisation and the patient signing a free and informed consent form. This work was not submitted to a Research Ethics Committee. The case report derived from an unplanned healthcare attendance, with no previous project design. The authors also respect patient privacy in the use of data and image. Searches were made in the literature using the MeSH database through the 
standardisation of the keywords. The discussion is based on previous publications on the subject.

\section{Case Report}

A 19-year-old male patient with neuropsychomotor development delay, ataxia, psychiatric disorders and sensorineural hypoacusis who was under investigation for a progressive neurodegenerative disease (neuronal ceroid lipofuscinosis) was hospitalised due to bleeding from the oral cavity and the presence of larvae. The patient was gastrostomised.

Intraoral clinical examination revealed a significant anterior open bite, mouth breathing, poor oral hygiene and the presence of numerous larvae, associated with extensive tissue necrosis in the maxillary region and inner face of the upper lip (Figure 1B). Computerised tomography of the face revealed involvement of the soft tissues associated with the upper lip and a focus of parasites in the palate region (Figure $2 \mathrm{~A}$ and $2 \mathrm{~B}$ ).

The diagnosis of myiasis of the oral cavity indicated the need for surgical intervention, which was performed under general anaesthesia. In view of the involvement of the upper airway, and due to the presence of numerous larvae and haemorrhage, nasotracheal intubation was performed with the aid of a fibre optic bronchoscope (Figure 1A). The larvae were excised, followed by the debridement of necrotic tissues in the maxilla and inner face of the upper lip (Figure 1C). At the time, 262 larvae were removed (Figure 3A). Prior to the intervention, the patient was treated with ivermectin $(200 \mu \mathrm{g} / \mathrm{kg})$ in a single dose via gastric tube, and with amoxicillin $(1 \mathrm{~g})$ associated with clavulanic acid (200 $\mathrm{mg})$, intravenously, for seven days. The larvae were of the species Cochliomyia hominivorax (Figure 3B). During hospitalisation, the intraoral wound was sanitised with $3 \%$ hydrogen peroxide (10 volumes) diluted in water (1:3 to 1:5), three times a day. Twice a day tooth brushing started from the third postoperative day. The patient was discharged from the hospital on the seventh day after the intervention. The patient's relatives and caregivers were instructed on the regimen of oral wound care, oral hygiene, protection of the oral cavity and environment care. The 10-day postoperative clinical control examination showed tissue reorganisation associated with the operated region was present, with no new larvae observed (Figure 3C). 
Figure 1. Treatment steps.

A. Use of fibre optic bronchoscope for nasotracheal intubation

B. Intraoral clinical aspect: presence of larvae, exudate and necrotic tissues

C. Immediate postoperative period: removal of larvae and tissue debridement
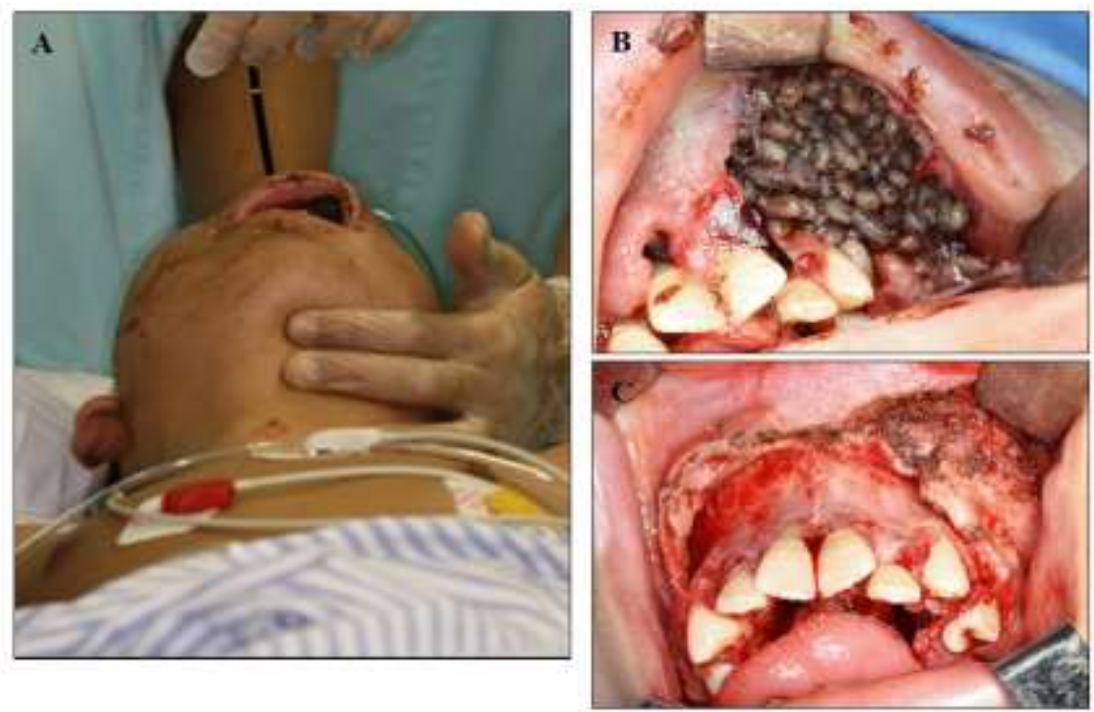

Source: Authors.

The large number of intraoral larvae, favouring the risk of aspiration, characterised a difficult airway in the patient. Nasotracheal intubation, performed by the anaesthesiologist, was performed with the help of a fibre optic bronchoscope. Airway protection was fundamental to avoid aspiration of larvae.

Figure 2. Computerised tomography of the face.
A. Sagittal image
B. Axial image
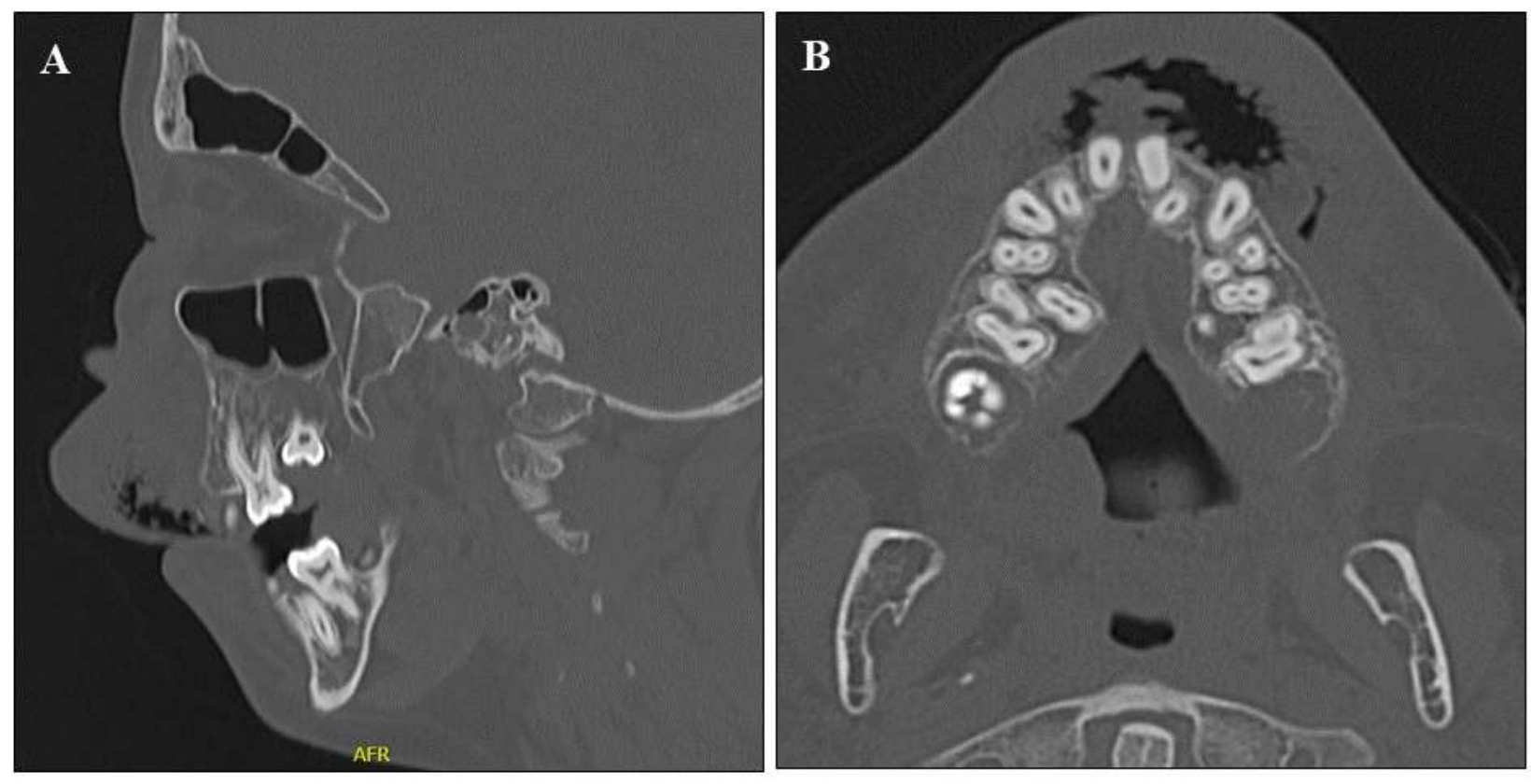

Source: Authors. 
Computerised tomography showed increased volume in the anterior region of the face, with dimensions of $4.9 \mathrm{~cm}$ in the transverse axis and $3.9 \mathrm{~cm}$ in the anteroposterior axis. Ulcerations were observed, compromising the region of the upper lip, anterior labiogingival groove and palatine gingiva, in the region of upper canines and incisors. There was no evidence of bone injury.

Figure 3. Larvae removed and postoperative control
A. Large number of larvae removed from the oral cavity
B. Larva of the species Cochliomyia hominivorax
C. Ten-day postoperative control
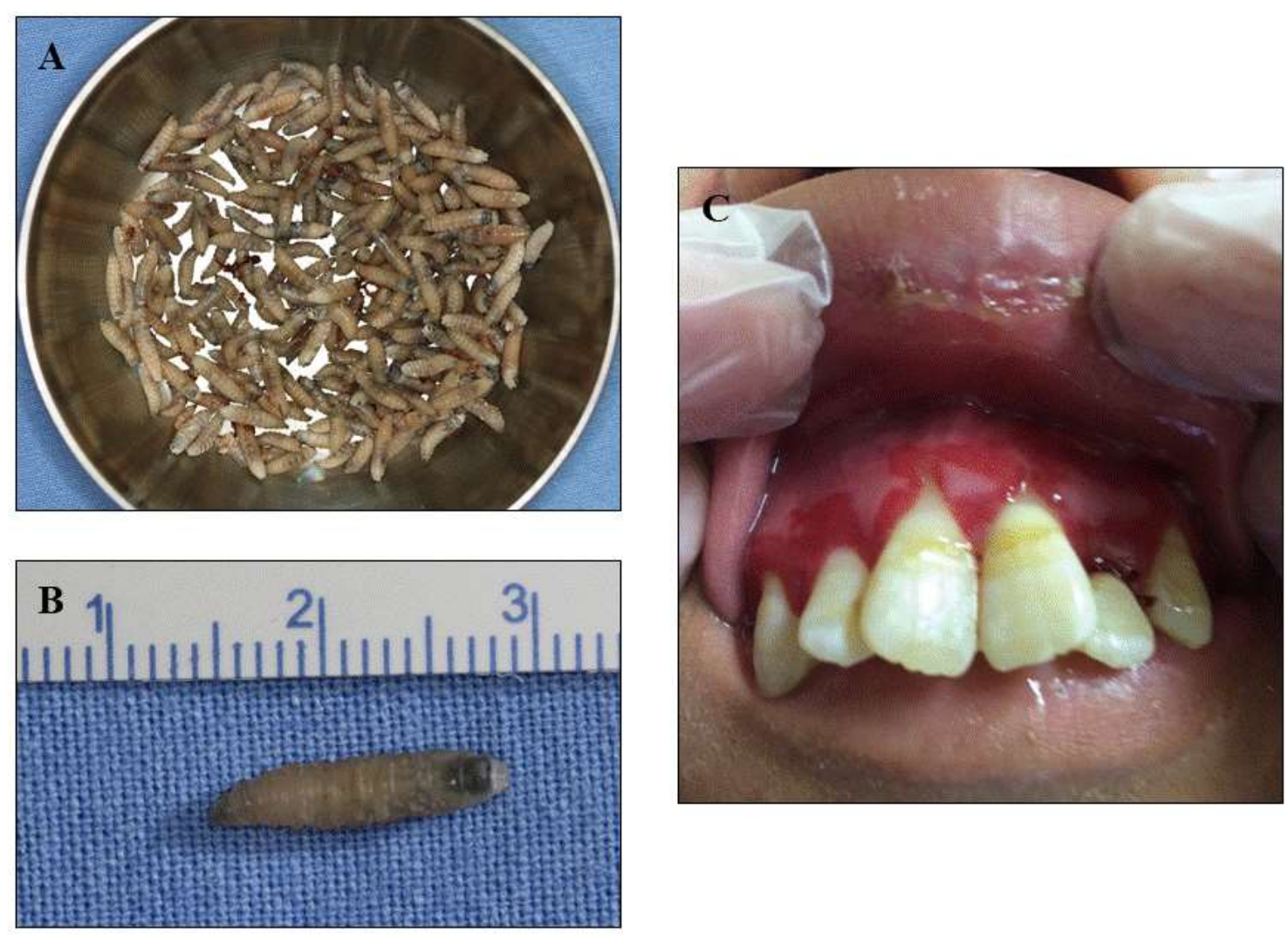

Source: Authors.

The large number of larvae removed from the oral cavity characterised the importance of the infestation. Postoperative control at an early stage (10 days) demonstrated that wound care and oral hygiene promote rapid intraoral tissue reorganisation.

\section{Discussion}

Human myiasis is more common as a subcutaneous infestation, but can also occur in wounds and body cavities, including the head and neck region (Bosmia, Zimmermann, Griessenauer, Shane Tubbs, \& Rosenthal, 2017; Filho, Dias, Miranda, \& Hebling, 2018; Faridnia et al., 2019; Huang et al., 2020; Lazaro et al., 2020; Pires et al., 2018; Singh \& Kaur, 2019; Uysal et al., 2018). 
In the head and neck region, the most commonly involved sites are the ears, eyes, nose, paranasal sinus, lymph nodes, mastoid region, tracheostomy wounds and oral cavity (Batista et al., 2019; Bosmia et al., 2017; de Arruda et al., 2017; Duque \& Ardila, 2011; Huang et al., 2020; Pires et al., 2018; Serafim, do Espírito Santo, de Mello, Collin, \& Deps, 2020). Oral myiasis is considered a rare condition of low incidence in healthy people (Filho et al., 2018; Ribeiro et al., 2012). When it occurs, it is associated with predisposing local, systemic and environmental factors. Local factors include poor oral hygiene, periodontal disease, suppurative lesions, mouth breathing, incompetent lips, anterior open bite, finger sucking habit, halitosis and trauma. Systemic factors include cerebral palsy, epilepsy, neurological deficits, poor general hygiene, alcoholism, mental health problems and senility. Finally, environmental factors include poor hygiene, low socioeconomic status, humid and warm climate, and exposure in endemic areas. Some cases are secondary to medical or anatomical conditions, such as oral cancer, malignant tumours and neglected fractures (de Arruda et al., 2017; Duque \& Ardila, 2011; Girardi \& Scrofernecker, 2017; Lazaro et al., 2020; Pires et al., 2018; Serafim et al., 2020; Shahi, Shrestha, Latheef, Bhandari, \& Shrestha, 2019; Zhang, Jiang, Luo, Ling, \& Wang, 2020). In the present case, the clinical condition of the patient, associated with facial characteristics (mouth breathing, anterior open bite, lip incompetence), poor oral hygiene and lack of hygiene control in the convivial environment, were determinant for the development of intraoral myiasis. Flies are attracted to the smell of necrotic tissue and the presence of secretions, such as blood (Bernhardt et al., 2019).

The larvae were identified as Cochliomyia hominivorax. Even though entomological identification is not essential for treatment, it is useful for epidemiological survey (Ahmadpour et al., 2019; de Arruda et al., 2017). This species is common in Brazil, and the life cycle of the fly begins with an egg, followed by the larval stage, pupa and finally, evolving into an adult fly. The incubation period of the eggs varies from 11-21 hours and the newly hatched larvae penetrate the tissues of the hosts from which they feed, maintaining the spiracles facing the outside. The larval cycle takes between four and eight days, during which they serve as parasites for humans. The invasion promoted by the larvae results in mucoperiosteal detachment and the presence of necrotic ulcers. The larvae hide deep in the tissues, seeking a niche for the development of pupae. The clinical diagnosis is usually made by the presence and movement of the larvae (de Arruda et al., 2017; Batista et al., 2019; Vasanthakumar, Varalakshmi, \& Vanmathi, 2020).

In the early stages, intraoral myiasis may be asymptomatic, but when left untreated, it can potentially generate complications, such as extensive tissue destruction, oral-sinus/oral-nasal communication, cavernous sinus thrombosis, secondary infections, and sepsis. The systemic state of the patient is determinant for a good prognosis (de Arruda et al., 2017; Faridnia et al., 2019; Filho et al., 2018). As the condition evolves, pain becomes a presenting symptom and bleeding occurs (Ahmadpour et al., 2019). Upper airway obstruction caused by myiasis requiring emergency intubation has also been reported (Teah, Chu, Shanmuganathan, \& Yeap, 2020). In the presented clinical case, the presence of numerous larvae in the oral cavity characterised the patient as having a difficult airway. This condition determined the need for orotracheal intubation with the aid of a fibre optic bronchoscope.

The treatment of intraoral myiasis consisted of mechanical removal of the larvae, surgical debridement and administration of antiparasitic and antimicrobial drugs. All larval residues were removed, thus avoiding secondary infections. Surgical debridement promoted the removal of all necrotic tissue (de Arruda et al., 2017; Filho et al., 2018). The antiparasitic drug used was ivermectin, which is a drug of the macrolide family, synthesised from natural substances, such as ivermectin (obtained from actinomycetes). It is a broad-spectrum antiparasitic drug for veterinary use, but has shown efficacy for some parasites that infect humans. For the treatment of human myiasis, it is usually given in a single dose of $150-200 \mu \mathrm{g} / \mathrm{kg}$ based on body weight (Girardi \& Scrofernecker, 2017; Filho et al., 2018; Vasanthakumar et al., 2020). The substance blocks impulses in the nerve endings of the parasites, causing paralysis and death of the larvae (Vasanthakumar et al., 2020). The use of ivermectin may interfere with the action of drugs that act on the central nervous system that are used for neurological 
treatment. Neurotoxicity can be influenced by the overexpression of glycoprotein P, favouring the entry of the drug into brain tissue through the blood brain barrier (Ribeiro et al., 2012). The theoretical concern regarding the potential of neurotoxicity of ivermectin in childhood (in children weighing less than $15 \mathrm{~kg}$ ) has not been addressed. The drug has been show to be effective and safe in controlling myiasis in paediatric patients (Jittamala et al., 2021). Prior to the emergence of ivermectin, especially for the treatment of furuncular lesions, the topical use of cigarette smoke, saline, sulfuric ether, olive oil, gentian violet, petroleum jelly, animal fat, nail polish, turpentine oil, phenol, chloroform, turpentine, hydrogen peroxide, chlorhexidine and other veterinary topical worm killers have been reported. All these substances, previously reported in the literature, were used with the objective of promoting tissue hypoxia and inducing the outflow of larvae from inside the tissues (Calvopina et al., 2020; Filho et al., 2018; Girardi \& Scrofernecker, 2017).

\section{Final Considerations}

Intraoral myiasis is prevented by controlling predisposing local, systemic and environmental factors. In the case of patients with some degree of immobility and presenting with dentofacial alterations, such as mouth breathing, open bite and lip incompetence, caregivers should be instructed on strict attention to oral inspection and hygiene, protection of natural cavities (use of masks by the patient) and control of causative agents (dipteran flies).

\section{References}

Ahmadpour, E., Youssefi, M. R., Nazari, M., Hosseini, S. A., Rakhshanpour, A., \& Rahimi, M. T. (2019). Nosocomial Myiasis in an Intensive Care Unit (ICU): A Case Report. Iranian journal of public health, 48(6), 1165-1168.

Alsaywid, B. S., \& Abdulhaq, N. M. (2019). Guideline on writing a case report. Urology annals, 11(2), 126-131.

Ashour D. S. (2019). Ivermectin: From theory to clinical application. International journal of antimicrobial agents, 54(2), 134-142.

Batista, C., Cantanhede, A., Fonseca de Sena, J., Barreto, S., Galvão-Moreira, L. V., \& Eduardo Batista, J. (2019). Nasosinusal myiasis in elderly patient with mucocutaneous leishmaniosis. Journal of stomatology, oral and maxillofacial surgery, 120(2), 164-166.

Bernhardt, V., Finkelmeier, F., Verhoff, M. A., \& Amendt, J. (2019). Myiasis in humans-a global case report evaluation and literature analysis. Parasitology research, 118(2), 389-397.

Bosmia, A. N., Zimmermann, T. M., Griessenauer, C. J., Shane Tubbs, R., \& Rosenthal, E. L. (2017). Nasal Myiasis in Hinduism and Contemporary Otorhinolaryngology. Journal of religion and health, 56(4), 1263-1281.

Britto, L. G., Oliveira, M. C. S., Giglioti, R., Barbieri, F. S., da Silva Netto, F. G., Chagas, A. C. S. \& Celestino, O. O. (2008). Manual de identificação, importância e manutenção de colônias estoque de dípteras de interesse veterinário em laboratório. Embrapa Rondônia.

Calvopina, M., Ortiz-Prado, E., Castañeda, B., Cueva, I., Rodriguez-Hidalgo, R., \& Cooper, P. J. (2020). Human myiasis in Ecuador. PLoS neglected tropical diseases, 14(2), e0007858.

Costa-Júnior, L. M., Chaves, D. P., Brito, D., Santos, V., Costa-Júnior, H. N., \& Barros, A. (2019). A review on the occurrence of Cochliomyia hominivorax (Diptera: Calliphoridae) in Brazil. Revista brasileira de parasitologia veterinaria = Brazilian journal of veterinary parasitology : Orgao Oficial do Colegio Brasileiro de Parasitologia Veterinaria, 28(4), 548-562.

de Arruda, J., de Oliveira Silva, L. V., Silva, P., de Figueiredo, E. L., Callou, G., Mesquita, R. A., \& do Egito Vasconcelos, B. C. (2017). Head and neck myiasis: a case series and review of the literature. Oral surgery, oral medicine, oral pathology and oral radiology, 124(5), e249-e256.

Duque, F. L., \& Ardila, C. M. (2011). Oral myiasis caused by the screwworm Cochliomyia hominivorax treated with subcutaneous ivermectin and creolin: report of six cases after trauma. Dental traumatology: official publication of International Association for Dental Traumatology, $27(5), 404-407$.

Estrela, C. (2018). Metodologia científica: Ciência, ensino e pesquisa. Arte Med.

Faridnia, R., Soosaraei, M., Kalani, H., Fakhar, M., Jokelainen, P., Zolfaghari Emameh, R., Banimostafavi, E. S., \& Ziaei Hezarjaribi, H. (2019). Human urogenital myiasis: A systematic review of reported cases from 1975 to 2017 . European journal of obstetrics, gynecology, and reproductive biology, 235, 5761.

Filho, A. O., Dias, D., Miranda, Á., \& Hebling, E. (2018). Oral myiasis in older adult with severe Alzheimer's disease. Special care in dentistry: official publication of the American Association of Hospital Dentists, the Academy of Dentistry for the Handicapped, and the American Society for Geriatric Dentistry, 38(2), 99-106.

Girardi, F. M., \& Scrofernecker, M. L. (2017). Myiasis in patients with head and neck cancer: Seldom described but commonly seen. Ear, nose, \& throat journal, 96(7), E19-E22. 
Huang, Y. L., Liu, L., Liang, H., He, J., Chen, J., Liang, Q. W., Jiang, Z. Y., He, J. F., Huang, M. L., \& Du, Y. (2020). Orbital myiasis: A case report and literature review. Medicine, 99(4), e18879.

Jittamala, P., Monteiro, W., Smit, M. R., Pedrique, B., Specht, S., Chaccour, C. J., Dard, C., Del Giudice, P., Khieu, V., Maruani, A., Failoc-Rojas, V. E., Sáez-de-Ocariz, M., Soriano-Arandes, A., Piquero-Casals, J., Faisant, A., Brenier-Pinchart, M. P., Wimmersberger, D., Coulibaly, J. T., Keiser, J., Boralevi, F., Kobylinski, K. C. (2021). A systematic review and an individual patient data meta-analysis of ivermectin use in children weighing less than fifteen kilograms: Is it time to reconsider the current contraindication? PLoS neglected tropical diseases, 15 (3), e0009144.

Kuria, S. K., \& Oyedeji, A. O. (2020). Human myiasis cases originating and reported in africa for the last two decades (1998-2018): A review. Acta tropica, 210, 105590 .

Laurence, S. M. (1909). Dipterous larvae infection. British Medical Journal, 9, 88.

Lazaro, S. A., Yépez, F., De Carli, J. P., Trentin, M. S., Dogenski, L. C., \& De Conto, F. (2020). Treatment of facial myiasis in an elderly patient with oral squamous cell carcinoma: Case report. International journal of surgery case reports, 71, 260-265.

Pires, W. R., Puttini, I. O., Oliva, A. H., Jacob, R., Figueira, H. C., Júnior, Sonoda, C. K., Faverani, L. P., Souza, F. Á., \& Garcia Júnior, I. R. (2018). Oral Myiasis in a Patient With HIV Manifestations and Neurologic Toxoplasmosis Treated by Ivermectin. The Journal of craniofacial surgery, 29(6), e555-e556.

Ribeiro, A. L., de Almeida, T. E., Lopes, J. S., Jr, Castro, J. F., \& Pinheiro, J. (2012). Oral myiasis: does an indication for surgical treatment still exist? Two case reports. Oral surgery, oral medicine, oral pathology and oral radiology, 114(3), e10-e14.

Serafim, R. A., do Espírito Santo, R. B., de Mello, R., Collin, S. M., \& Deps, P. D. (2020). Case Report: Nasal Myiasis in an Elderly Patient with Atrophic Rhinitis and Facial Sequelae of Leprosy. The American journal of tropical medicine and hygiene, 102(2), 448-450.

Shahi, S., Shrestha, S. D., Latheef, M. A., Bhandari, T. R., \& Shrestha, D. (2019). Traumatic Lower Lip Myiasis-A Rare Presentation. JAMA otolaryngology-head \& neck surgery, 145(2), 194-195.

Singh, A., \& Kaur, J. (2019). Occurrence of human urogenital myiasis due to neglected personal hygiene: a review. Transactions of the Royal Society of Tropical Medicine and Hygiene, 113(1), 4-10.

Teah, M. K., Chu, Y. M., Shanmuganathan, S. D., \& Yeap, T. B. (2020). Massive airway myiasis: an extreme rarity. BMJ case reports, $13(12)$, e237764.

Uysal, S., Ozturk, A. M., Tasbakan, M., Simsir, I. Y., Unver, A., Turgay, N., \& Pullukcu, H. (2018). Human myiasis in patients with diabetic foot: 18 cases. Annals of Saudi medicine, 38(3), 208-213.

Vasanthakumar, V., Varalakshmi, P. R., \& Vanmathi, R. (2020). Oral Myiasis of Maxilla (Palatal Gingiva). Contemporary clinical dentistry, 11(2), 162-164.

Zhang, T. Z., Jiang, Y., Luo, X. T., Ling, R., \& Wang, J. W. (2020). Oral myiasis after cerebral infarction in an elderly male patient from southern China: A case report. World journal of clinical cases, 8(24), 6499-6503. 